\title{
Semi-quantitative detection for L.asparaginase producing fungi and the impact of carbon and nitrogen sources on enzyme activity
}

\author{
Mahdi Hamed ${ }^{1,2}$, Ahmed A Osman ${ }^{1}$, Mustafa Ateş² \\ ${ }^{1}$ Al-Neelain University, Department of Microbiology and Molecular Biology, Khartoum, \\ Sudan. \\ ${ }^{2}$ Ege University, Department of Basic and Industrial Microbiology, İzmir, Türkiye. \\ * Correspondence to: Ahmed A Osman (PhD) \\ Al Neelain University, \\ Department of Microbiology and Molecular Biology, Khartoum, \\ Sudan, P.O. Box 12702, \\ Postal code 11121 \\ Mobile:: +249908589873 \\ E-mail: ahmedalhai203@gmail.com
}

\begin{abstract}
Objective

To semi-quantitively screen filamentous fungi isolated from different habitats for L-asparaginase production by three indicators; phenol red, cresol red and bromothymol blue and to examine the impact of different carbon and nitrogen sources on the enzyme production using different fungal isolates.
\end{abstract}

\section{Materials and methods}

Fifty-five fungal isolates were tested for L-asparaginase production by plate assay using Modified Czapek-Dox (MCD) medium. The enzyme activity was estimated using the Nessler method which measures the concentration of ammonia formed owing to the enzyme action on the substrate. The impact of nitrogen and carbon sources on the enzyme production was done by using the best three L. asparaginase producers from the semi-quantitative screening.

\section{Results and conclusions}

A total of 53/55 $(96.36 \%)$ fungal isolates were L-asparaginase producing strains, of them, Cladosporium tenuissimum, Penicillium camembertii and Aspergillus carneus showed high enzyme production. Production of L-asparaginase was higher with the glucose and urea as carbon and nitrogen sources, respectively. The highest enzyme level $(5,558 \mathrm{U} / \mathrm{ml})$ was produced by $C$. tenuissimum in a glucose-containing medium. This study shows that $P$. camemberti, $A$. carneus, and $C$. tenuissimum are good L-asparaginase producers and thus could be used for L_asparaginase production

Keywords: L_asparaginase, anticancer, indicator, fungi, carbon source, nitrogen source. 


\section{Introduction}

L-Asparagine amido hydrolase (L-asparaginase, E.C.3.5.1.1), is an enzyme catalyzes the conversion of L-asparagine to L-aspartic acid and ammonia [1]. L-asparaginase produced by plants, animals and microbes, and It has been used as effective treatment of children with acute lymphoblastic leukemia and in processing fried and baked food products which might contain a carcinogenic compounds[2].

Due to their ability to be cultured in an inexpensive substrate, easiness of optimization and purification techniques and to metabolically engineered, microbes are the preferred source of the enzyme [2,3], however, pharmaceutically L-asparaginase is obtained primarily from Escherichia coli and Erwinia carotova is associated with undesired hypersensitivity and decreased enzyme activity [4, 5]. Thus, owing to the non-toxicity of L-asparaginase of an eukaryotic sources, filamentous fungi have been explored for the enzyme with least unfavorable effects [18].

\section{Material and methods}

\section{Microorganisms:}

Fifty-five filamentous fungal isolates were obtained from the stocks of the Laboratories of three Turkish universities, Ege university, Adnan Mendres university and Celal Bayar university. Fungal isolates were maintained by cultivation in a slant of potato dextrose agar.

\section{Semi-quantitative production of L-asparaginase}

Fungal strains screened for enzyme production on MCD medium, components g/litre; glucose: 2.0, L-asparagine: 10, $\mathrm{KH}_{2} \mathrm{PO}_{4}: 3.0, \mathrm{Na}_{2} \mathrm{HPO}_{4}$ : 6.0, MgSO4.7 $\mathrm{H}_{2} \mathrm{O}: 0.50, \mathrm{NaCl}: 0.50, \mathrm{FeSO}_{4}: 0.03$, $\mathrm{CuNO}_{3} .3 \mathrm{H}_{2} \mathrm{O} 0.03, \mathrm{ZnSO}_{4} .7 \mathrm{H}_{2} \mathrm{O} 0.05, \mathrm{CaCl}_{2}$ : 0.05, agar: 20, indicator: 0.009) [6]. Inoculated plates were inoculated for $96 \mathrm{~h}$ at $30{ }^{\circ} \mathrm{C}$. The strains that showed a zone of change in colour around the colonies indicated L-asparaginase production. Semi-quantitative screening was performed as described by Gonçalves et al. [7].

\section{L-asparaginase production via submerged fermentation}

Fifty $\mathrm{ml}$ of sterile MCD production medium, g/litre (glucose: 2.0, L-asparagine: $10, \mathrm{KH}_{2} \mathrm{PO}_{4}: 1.52$, $\mathrm{MgSO} 4.7 \mathrm{H}_{2} \mathrm{O}: 0.52, \mathrm{KCl}: 0.52, \mathrm{FeSO}_{4}: 0.03, \mathrm{CuNO}_{3} .3 \mathrm{H}_{2} \mathrm{O} 0.03, \mathrm{ZnSO}_{4} .7 \mathrm{H}_{2} \mathrm{O} 0.05$ ) in a $250 \mathrm{ml}$ Erlenmeyer flask was used for production. The bottles were incubated for 96 hours $\left(30^{\circ} \mathrm{C}\right.$ and 150 $\mathrm{rpm})$, then to separate the fungal cell mass, centrifuged at $5000 \mathrm{rpm}$ for 15 minutes at $4{ }^{\circ} \mathrm{C}$. The supernatant was used as a raw enzyme source to determine enzyme activity $[8,9,10]$.

\section{Effect of carbon source:}

Using three isolates, A. carneus, $P$. camemmberti and C. tenuissimum the effect of glucose, starch, lactose, glycerol and sucrose on enzyme production was investigated. The MCD production medium was prepared with a concentration of $0.2 \%$ of the carbon source mentioned above. The flaks were incubated as mentioned above (section 2.3). Enzyme activity test was done after 96 hours.

\section{Effect of nitrogen source}

Using three isolates (A. carneus, $P$. camemmberti and C. tenuissimum), the impact of proline, urea, asparagine, ammonium chloride and sodium nitrate on enzyme production was investigated. The production medium was prepared with a concentration of $0.5 \%$ of the nitrogen source mentioned above. $0.5 \%$ asparagine was added as an inducer for ${ }_{L}$-asparaginase production. The flasks were placed as in section 2.3. Enzyme activity test was done after 96 hours. 


\section{Results and discussion}

\section{Screening}

Fifty-three filamentous fungal isolates out of 55 isolates $(96.36 \%)$ showed a positive reaction for the production of L-asparaginase enzyme as seen due to the color change in a zone surrounding the colonies. Only 2 isolates (2/55 3.63\%) (Penicillium. islandicum P7 and Phoma sp.) didn't show any change of color of any used indicator. Two isolates of Eurotium amstelodami didn't show any color change in phenol red and bromothymo, containing media but showed a slight color change of zone in the cresol red medium.

\section{Semi-quantitative screening:}

In semi-quantitative screening, we found that $P$. camembertii (3.18 EAR) (Figure 1-a), $C$. tenuissimum (3.66 EAR) (Figure 1-b) and A. carneus (3.18 EAR) (Figure 1-c) were the best Lasparaginase strain producer among the tested isolates. Also our results showed that bromothymol blue showed a stronger colour contrast and larger EAR compared with phenol red and cresol red. This result ties well with previous study carried by Mahajan et al. [11] Wherein bromothymol blue (BTB) used instead of phenol red as $\mathrm{pH}$ indicator in L-asparagine-containing medium to distinguish between L-asparagine producers and non-producers fungal isolates, $\mathrm{L}$-asparagine producers formed dark blue zone around Fungal colonies (medium supplemented with BTB at acidic pH are yellow and it changes to blue at alkaline $\mathrm{pH}$ ). These authors concluded that BTB is more sensitive and accurate. However, this result contrary to the findings of Mihooliya et al. [6] who showed that zone of hydrolysis produced by L-asparagine producing bacteria in media supplemented with cresol red is efficient, better differentiable and consistent contrary to phenol red and BTB, we speculate that this might be

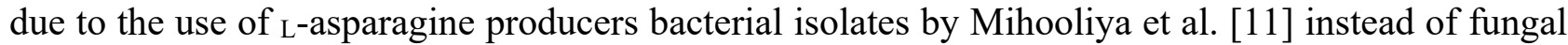
isolates.

\section{Effect of carbon source}

Our results showed that all the isolates produced different ${ }_{\mathrm{L}}$-asparaginase levels in MCD medium containing $0.2 \%$ carbon sources. The highest L-asparaginase levels $(5.558 \mathrm{U} / \mathrm{ml}),(4.95 \mathrm{U} / \mathrm{ml})$ and (4.923 U/ml) were produced by $C$. tenuissimum, $A$. carneus and $P$. camemberti, respectively in MCD medium containing $0.2 \%$ glucose (Figure 2). These findings are consistent with research done by Gurunathan and Sahadevan [12], Raja et al.[13] and Zia et al. [14].

\section{Effect of nitrogen sources}

Also our results demonstrated that there was a high degree of variation regarding the level of produced L-asparaginase when changing the type of nitrogen source in MCD medium. A. carneus and $P$.

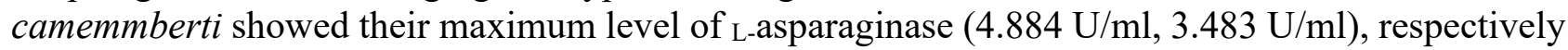
when cultivated in MCD media supplemented with ammonium chloride. Moreover, in this study we found that using urea as nitrogen source produced the highest level of $\mathrm{L}_{\mathrm{L}}$ asparaginase $(5.015 \mathrm{U} / \mathrm{ml})$ by C. temimmisium (Figure 3). The effect of supplementation of ammonium chloride, urea and sodium nitrate as nitrogen sources was studied on growth and production of L-asparaginase by A. terreus. Urea was identified as the best supplementary nitrogen source [10]. Abbas Ahmed et al. [16] and Sarquis et al. [17] have shown that urea had lowest production of L-asparaginase.

Generally, proline was a poor substrate, isolates reached their lowest LA levels in a proline-containing medium (Figure 5) which is contradicting the result of Sarquis et al. [17]. The contradiction probably might be due to the difference in the used organism for production. 


\section{Conclusion}

This study showed that Penicillium and Aspergillus species can produce L-asparaginase at different levels. Bromothymol blue is the best indicator for screening fungal LA producer. P. camemberti, A. carneus, and $C$. tenuissimum are good LA producing isolates. The carbon/nitrogen sources present in the production environment can affect the level of LA produced by the fungi. Glucose is the best carbon source whereas urea was the best nitrogen source for LA production.

\section{Conflicts of interest}

The authors declare there are no conflicts of interest. 
bioRxiv preprint doi: https://doi org/10.1101/2021.02 02 429175. this version posted February 3, 2021. The copyright holder for this preprint (which was not certified by peer review) is the author/funder, who has granted bioRxiv a license to display the preprint in perpetuity. It is made available under aCC-BY-NC-ND 4.0 International license.
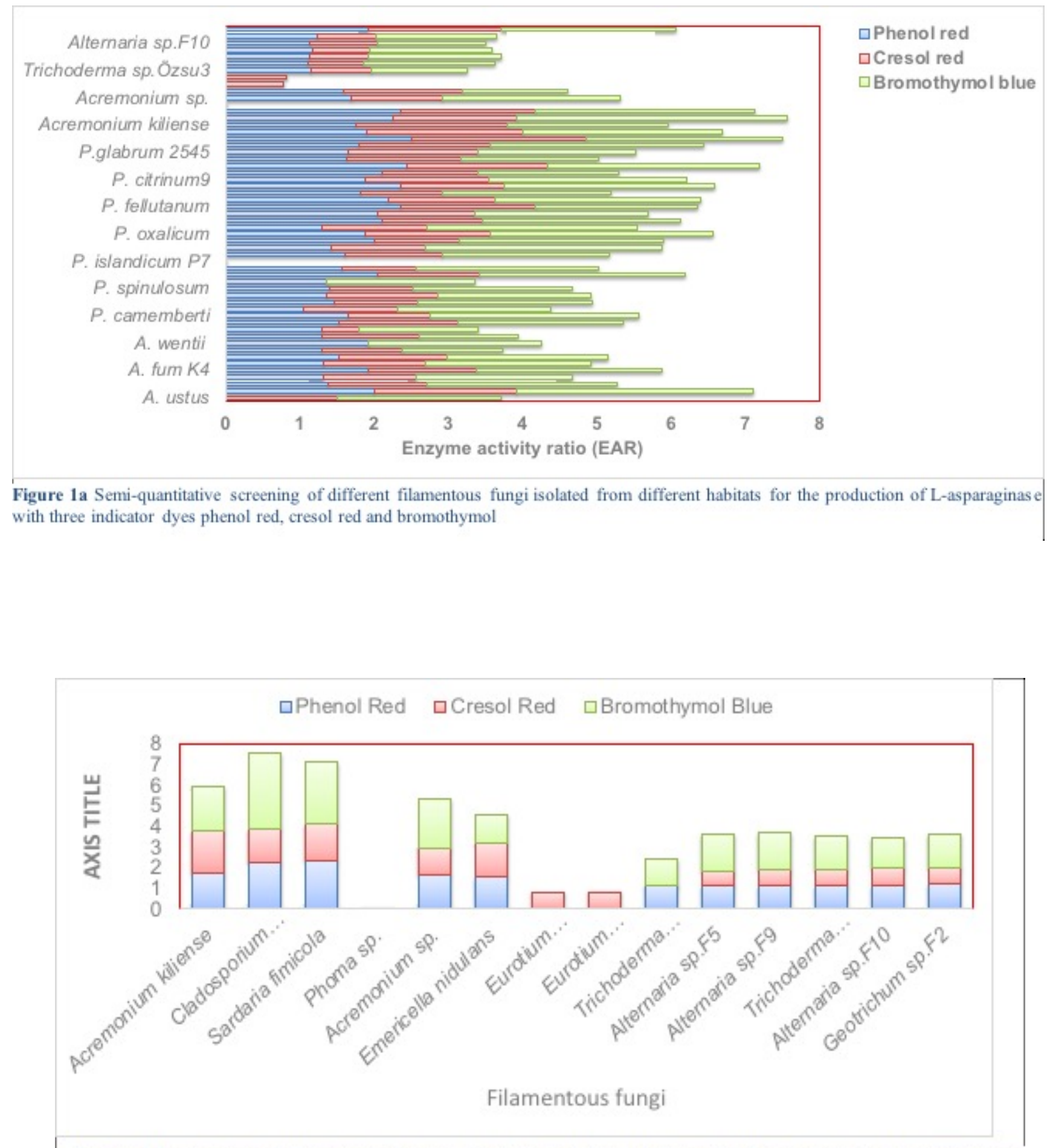

Figure 1-b screening of filamentous fungi isolated from different habitats for the production of Lasparaginas with three indicator dyes phenol red, cresol red and bromothymol 
bioRxiv preprint doi: https://doi.org/10.1101/2021.02.02.429175. this version posted February 3,2021 . The copyright holder for this preprint (which was not certified by peer review) is the author/funder, who has granted bioRxiv a license to display the preprint in perpetuity. It is made available under aCC-BY-NC-ND 4.0 International license.
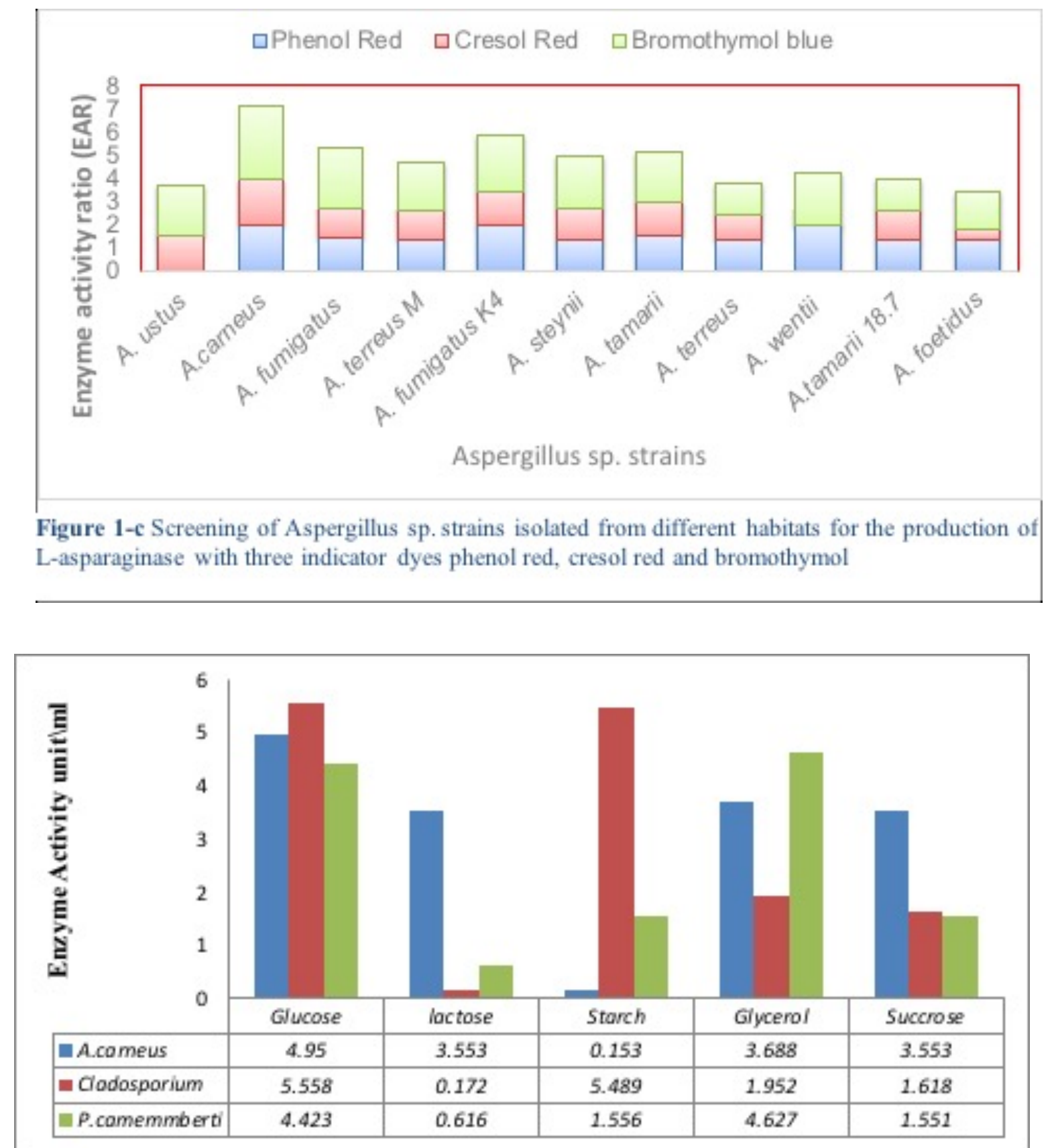

Figure 2 Impact of carbon sources on L-asparaginase production using three different fungal species. 
bioRxiv preprint doi: https://doi.org/10.1101/2021.02.02.429175; this version posted February 3, 2021. The copyright holder for this preprint (which was not certified by peer review) is the author/funder, who has granted bioRxiv a license to display the preprint in perpetuity. It is made available under aCC-BY-NC-ND 4.0 International license.

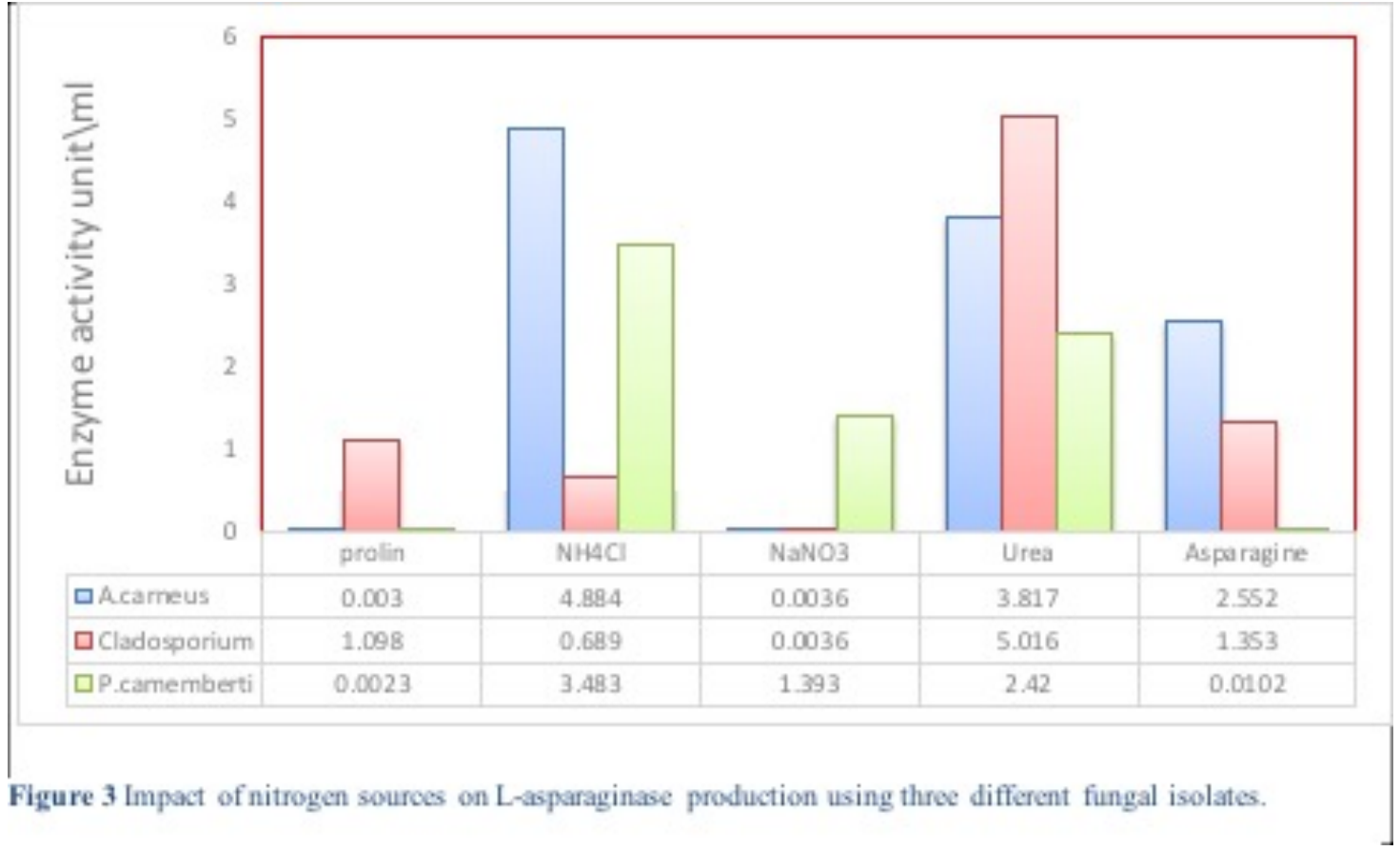




\section{References}

1. Meghavarnam, A.K. and Janakiraman S., 2015, A Simple And Efficient Dye-Based Technique For Rapid Screening Of Fungi For L-Asparajinase Production, Journal of Experimental Biology and Agricultural Sciences, 3(2): 123-130.

2. Vimal, A. and Kumar, A., 2017, In Vitro Screening And In Silico Validation Revealed Key Microbes Forhigher Production Of Significant Therapeutic Enzyme LAsparajinase, Enzyme and Microbial Technology, 98: 9-17 p.

3. Souza, P.M., De Freitasa, M.M., Cardosoa, S.L., Pessoab, A., Guerrac, E.N.S. and Magalhães, P.O., 2017, Optimization and purification of L-asparajinase from fungi: A systematic review, Critical Reviews in Oncology/Hematology 120: 194-202.

4. Cachumba, J.J.M., Antunes, F.A.F., Dias Peres, G.F., Brumano, L.P., Dos Santos, J.C. and Da Silva, S.S., 2016, Current applications and different approaches for microbial L-asparajinase production, Brazilian Journal of Microbiology, 47: 77-85 p.

5. Monica, T., Lincoln, L., Niyonzima, F.N., and Sunil, S.M., 2013, Isolation, Purification and Characterization of Fungal Extracellular L-Asparaginase from Mucor hiemalis. Journal Biocatalysis Biotransformation 2:2. doi:10.4172/2324-9099.1000108.

6. Mihooliya, K.N., Nandal, J., Swami, L., Verma, H., Chopra, L. and Sahoo, D.K., 2017, A New pH Indicator Dye-Based Method For Rapid And Efficient Screening Of Lasparajinase Producing Microorganisms, Enzyme and Microbial Technology, 107: 72$81 \mathrm{p}$.

7. Gonçalves, A.B., Maia, A.C.F., Rueda, J.A. and Vanzela, A.P.F.C., 2016, Fungal Production Of The Anti-Leukemic Enzyme L-Asparajinase: From Screening To Medium Development, Acta Scientiarum Biological Sciences, 38(4): 387-394 p.

8. Kumar, R., Sedolkar, V.K., Triveni, A.G., Kumar, M.S., Shivannavar, C.T. and Subhaschandra, M.G., 2016, Isolation, Screening and Characterization Of LAsparajinase Producing Fungi From Medicinal Plants, Int J Pharm Pharm Sci, 8(1): 281-283 p.

9. El-Hadi, A.A., EL-Refai, H.A., Shafei, M.S., Zaki, R. and Mostafa, H., 2017, Statistical Optimization Of L-Asparajinase Production By Using Fusarium solani, Egyptian Pharmaceutical Journal, 16:16-23 p.

10. Kumar, M.N.S. and Manonmani, H.K., 2013, Purification, Characterization And Kinetic Properties Of Extracellular L-Asparajinase Produced By Cladosporium sp. World Journal of Microbiology and Biotechnology, 29(4): 577-587 p.

11. Mahajan, R.V., Saran, S., Saxena R.K. and Srivastava, A.K., 2013, A Rapid, Efficient And Sensitive Plate Assay For Detection And Screening Of L-Asparaginase-Producing Microorganisms, FEMS Microbiol Lett, 341: 122-126 p.

12. Gurunathan, B. and Sahadevan, R., 2011, Production of L-asparajinase from Natural Substrates by Aspergillus terreus MTCC 1782: Optimization of Carbon Source and Operating Conditions, International Journal of Chemical Reactor Engineering, 9: A73. 
13. Raja, M.M.M., Raja, A., Salique, S.M. and Gajalakshmi, P., 2016, Comparative Studies On Effect Of Carbon And Nitrogen Sources On L-Asparajinase Production International Journal of Applied Science Biotechnol, 4(4): 452-45 p.

14. Zia, M.A., Bashir, R., Ahmed, I. and Iftikhar, T., 2013, Production of LAsparajinase from Aspergillus Niger using Agro Wastes By-Products in Submerged Fermentation Process. Jurnal Teknologi (Sciences \& Engineering), 62(2): 47-51 p.

15. Baskar, G., Sriharini, C., Sripriya, R. and Renganathan, S., 2010, Statistical Screening of Supplementary Nitrogen Source for Enhanced Production of L-Asparajinase by Aspergillus terreus 1782, Chem. Biochem. Eng. Q. 24(4): 467-472 p.

16. Abbas Ahmed, M.M., Nageh Abo Dahab, F., Taher Taha M. and Fareed Hassan S.M., 2015, Production, Purification and Characterization of L-Asparajinase from Marine Endophytic Aspergillus sp. ALAA-2000 under Submerged and Solid State Fermentation, J Microb Biochem Technol, 7: 165-172 p.

17. Sarquis, M.I.D.M., Oliveira, E.M.M., Santos, A.S. and Da Costa, G.L., 2004, Production of L-asparajinase by Filamentous Fungi, Mem Inst Oswaldo Cruz, Rio de Janeiro, 99(5): 489-492 p.

18. Patil, M. P., Patil, R. H., and Maheshwari, V. L. (2012). A novel and sensitive agar plug assay for screening of asparaginase-producing endophytic fungi from aegle marmelos. Acta Biol. Szeged. 52, 175-177. 